\title{
The Existence of the Religious Court in Handling Divorce Cases on the Reason of Domestic Violence
}

\author{
Dedi Sumanto ${ }^{1}$ \\ Titin Samsudin ${ }^{2}$ \\ Fikri Hi. Asnawi Amiruddin ${ }^{3}$
}

\begin{abstract}
${ }^{1}$ Faculty of Sharia, Sultan Amai State Islamic Institute Gorontalo, Indonesia. E-mail: dedisumanto@iaingorontalo.ac.id ${ }^{2}$ Faculty of Sharia, Sultan Amai State Islamic Institute Gorontalo, Indonesia. E-mail: titin.samsudin@iaingorontalo.ac.id ${ }^{3}$ Faculty of Sharia, Sultan Amai State Islamic Institute Gorontalo, Indonesia. E-mail: fikram.gtlo@gmail.com
\end{abstract}

\section{Article Info}

\section{Keywords:}

Religious

Divorce;

Courts;

Violence; PKDRT Law

How to cite (APA Citation Style):

Sumanto, D., Samsudin, T., Amiruddin, F.H.A. (2021). " The Existence of the Religious Court in Handling Divorce Cases on the Reason of Domestic Violence." JALREV 3 (2): 214-230

\begin{abstract}
Domestic violence results in any action against a person in the household, which results in physical, sexual, psychological misery or suffering, and or neglect of the household, including threats to commit acts, coercion, or deprivation of liberty unlawfully within the household. The problem that arises is the legal perspective on domestic violence and the existence and role of the Religious Court in handling divorce cases on the grounds of domestic violence. This writing uses a normative juridical research method with a case approach. The legal materials used consist of primary, secondary, and tertiary legal materials, then analyzed and drawn qualitative conclusions. The results of this study are in a review of Law Number 23 of 2004. Whatever its nature is, hitting the wife is one type of domestic violence prohibited by the PKDRT law. However, in essence, the law on domestic violence does not conflict with Islamic teachings because the law is made to protect the benefit of the community, namely protecting every member of the family or household from further acts of violence. The Religious Court has played an active role in applying the law in handling divorce cases on the grounds of domestic violence by applying the provisions of Article 39 paragraph 1 and paragraph 2 and the reasons for divorce in Article 19 of Government Regulation Number 9 of 1975.
\end{abstract}

@2021-Sumanto, D., Samsudin, T., Amiruddin, F.H.A..

Under the license CC BY-SA 4.0 


\section{Introduction}

In principle, marriage is intended for married life and eternal happiness for the husband and wife concerned. Article 3 of the Compilation of Islamic Law states that marriage aims to realize a sakinah, mawaddah, and grace household life. ${ }^{1}$ Meanwhile, Mohammad Daud Ali stated that the purpose of marriage is to form a happy family or household. This means that the rights and position of the husband are in balance with the rights and position of the wife in family life and the association of living together in society. ${ }^{2}$ Based on the noble purpose of the marriage, marriages that do not show sakinah, mawaddah wa rahmah are often found. There were even prolonged squabbles, resulting in divorce due to disharmony in the household.

A household is said to be harmonious if family members feel happy, which is characterized by the absence of conflict, tension, disappointment, and satisfaction with the whole family's situation (physical, mental, emotional, and social). The family is called disharmony if the opposite happens. ${ }^{3}$

Tension and conflict between husband and wife and parents and children is a natural thing in a household or family. No household runs without conflict, but conflict in the household is not something scary. Almost all families have experienced "no marriage without problems," said Ann Landers, marriage counselor from Chicago, United States, quoted by Nasaruddin Latif in his book Marriage Counseling. ${ }^{4}$

Problem-solving is done with excessive anger, physical beating as an outlet for anger, shouting and cursing, and scary expressions. Sometimes there are behaviors such as attacking, coercing, threatening, or violent physical. ${ }^{5}$ Such behavior can be said to be an act of domestic violence (in the future abbreviated as domestic violence) which is defined as any action against someone in the household, which results in physical,

\footnotetext{
${ }^{1}$ Abdurrahman. (1992). Compilation of Islamic Law, Cet. I. Jakarta: Akademika Pressindo. p. 114.

${ }^{2}$ Ali, M. D. (2002). Islamic Law and Religious Courts, (Collection of Writings), Cet. II. Jakarta: Raja Grafindo Persada. p. 44.

${ }^{3}$ Ahmad, B. and Yanti, Y. (2015). The Existence and Implementation of Islamic Law in Indonesia, Cet. I. Yogjakarta: Student Library. p.168-169.

4 Ibid., see, Latif, S. M. N. (2005). Marriage Counseling, Cet. II. Bandung: Hidayah Library. p. 267.

${ }^{5}$ Violence is a form of physical activity that results in injury, disability, or suffering to others. See, Wahid, A. and Irfan, M. (2001). Protection of Victims of Sexual Violence. Bandung: Refika Aditama. p. 30 .
} 
sexual, psychological misery or suffering, and or neglect of the household including threats to commit acts, coercion, or unlawful deprivation of liberty within the household.

The majority of victims of domestic violence are experienced by women (wives). However, this case is not widely revealed because women keep it more than tell others. It is considered a disgrace to the family that no one else should know unless only she and her husband know, acts of violence committed. This is called a hidden crime because the perpetrators and victims try to hide the acts of violence from the view of the surrounding community. ${ }^{6}$ Violence against women is caused more by the culture and values of the society that is shaped by patriarchal forces where men are culturally the determinants of life.

Deputy Chairman of the National Commission on Violence against Women, Budi Wahyuni said that, on average, cases of domestic violence were resolved mainly by choosing to divorce rather than punishing them. This is more because women victims of domestic violence feel taboo by reporting their husbands to the police. Victims of domestic violence prefer divorce because it is considered a fast, easy and cheap way. Divorce is considered an easy alternative to breaking the chain of violence. Another consideration is that the process to obtain justice is not easy and complicated, such as having to collect evidence (visum) and present witnesses. Wives, as victims, prefer to think about their children, such as how their children will react when they find out that their father is in prison because of a domestic violence lawsuit. The victims consider it, which may not be an objective but more subjective consideration. That is the gender construction. Women are more likely to give in because it is part of being concerned, part of the test process, and it is believed that patience will pay off. ${ }^{7}$

I referred to the 2019 annual records of the National Commission on Violence Against Women, recorded cases of violence against women received by various community institutions and government institutions spread across almost all provinces in

${ }^{6}$ Soeroso, M. H. (2010). Domestic Violence in Juridical-Victimological Perspective. Jakarta: Sinar Grafika. p. 1.

${ }^{7}$ Wardah, F. Korban KDRT Lebih Memilih Perceraian daripada Pidana. Retrieved from https://www.voaindonesia.com/a/korban-kdrt-masih-select-perbagian-daripada-pidana/5141998.html, (accessed April 18, 2021). 
Indonesia. Based on the data collected, the most prominent type of violence against women as in the previous year was domestic violence (personal domain), which reached $75 \%(11,105$ cases $)$. In the realm of domestic violence/RP, the most prominent violence is physical violence, 4,783 cases (43\%), taking the first place, followed by sexual violence with 2,807 cases (25\%), psychological 2,056 (19\%), and economic 1,459 cases (13\%). As for violence in the realm of household/personal relations. ${ }^{8}$

To anticipate this domestic violence phenomenon so that it does not drag on, the government views it is crucial to issue laws and regulations to overcome this domestic violence, so the Law of the Republic of Indonesia Number 23 of 2004 concerning the Elimination of Domestic Violence (PKDRT Law) was born. Before the birth of the PKDRT Law, crimes committed within the household scope against family members had not been considered one of the legal, social problems. The PKDRT Law hopes that the wider community can better carry out their rights and obligations within the scope of their household following the basis of their religion.

The Religious Court is the last point of reference for women victims of domestic violence. This causes the disclosure of violence itself to be not optimal because the Religious Court only has the authority to decide on civil elements while criminal acts are not touched. The separation between civil cases and (divorce lawsuits) and criminal cases in the Indonesian justice system does not benefit the interests of women victims to get justice because religious courts do not have the authority to handle criminal cases of domestic violence.

In general, from all divorce cases based on data obtained from the Junior Registrar of Laws of the Religious Court in 2019, there were 642 divorce cases. From the factors causing divorce, there were 17 cases caused by domestic violence or $2.65 \%$, while in 2020 , there were 583 cases and 28 cases or $4.80 \%$ caused by domestic violence factors. ${ }^{9}$

\footnotetext{
${ }^{8}$ Komnas Perempuan. (2020). 2019 Annual Record of Violence Against Women. Jakarta: Komnas Perempuan. p. 1.

${ }^{9}$ Junior Registrar of Law Registrar's Office of the Gorontalo Religious Court on February 3, 2021.
} 
Divorce lawsuits filed at the Religious Court on the grounds of domestic violence, in general, the causative factors are because they often drink alcohol until they are drunk, do not provide a living/economy, excessive blind jealousy, infidelity, husband and wife who get married at the same age. Not yet established, or the family's intervention, and from several divorce cases on the grounds of domestic violence that the Religious Court examined, it was indicated that it started after their household had been running for $> \pm$ one year or had children.

\section{Problem Statement}

In handling and resolving domestic violence cases at the Religious Court, there is no doubt that the level of judges on duty and has been professional in their field. However, sometimes the handling becomes a dilemma because judges have to try to keep the household or dissolve their household regardless of who is the cause and become the fundamental reason for the Religious Courts is that if they force a life together in such circumstances, it will be more dangerous for the survival of their household because it does not provide benefits. Hence, the best way for both is divorce. The research problems raised are about the legal perspective on domestic violence, and how is the existence and role of the Religious Court in handling divorce cases on the grounds of domestic violence.

\section{Methods}

The research method in this study is normative juridical legal research using a statutory approach and a case approach. Juridical research based on the jurisprudence school is research based on normative legal science (laws and regulations) but does not examine the norms that work in society.

\section{Discussion}

\subsection{Legal Perspectives on Domestic Violence}

According to Article 5 of Law No. 23 of 2004, violence in the domestic sphere is as follows: physical violence, psychological violence, sexual violence, or economic violence (domestic neglect). 


\section{a. Physical abuse}

Islamic teachings promote peace and non-violence. When violence occurs, family harmony is inevitably torn apart, and various tempests are inevitable. The mind suffers because the person who should have poured all his love and attention has turned his back by committing injustice in word and deed.

Among the forms of domestic violence that are sometimes forgotten among Muslims are feelings of hatred for their partners. A husband abuses his wife with harsh words, being rude and demanding perfection from his partner. He forgets that his wife also has advantages in addition to weaknesses that everyone cannot escape from

\section{b. Psychic Violence}

The wife experiences violence in the form of reproach with hurtful words, cursing, making fun of, intimidating, threatening to kill, or other actions that hurt the wife psychologically or emotionally. From a psychological point of view, women naturally have subtle feelings compared to men's feelings. In everyday practice in the household, words often arise that offend the wife, whether intentionally or not, especially when the husband is angry, rebukes, insults, and insults just come out.

As the head of the household, a husband is obliged to guide and educate him patiently so that he can become a pious wife and serve her husband with complete pleasure. Moreover, pray that Allah will fix it and make her a pious wife.

\section{c. Sexual Violence}

Sex is an instinct that is inherent in humans as well as in animals. Humans, besides being intelligent beings, are also sexual beings. In Islam, all human instincts have a valuable place. Sexual instincts must be channeled and must not be restrained. This restraint will have negative impacts not only on the body but also on the spiritual.

Ibn Qayyim al-Jauziyah said: "When semen is allowed to settle and cannot be channeled, it can result in the emergence of several mental illnesses that are dangerous and even people can go crazy because of it" (Ibn al Qayyim, Zaad al Maad, II/146). This 
applies to men and women because women are also given the same sexual instincts. In order to meet the demands of this instinct, Islam regulates marriage or household. ${ }^{10}$

Sexual violence is prohibited in Islam because it demeans human dignity, both the dignity of the perpetrator and even more so, the dignity of the victim. The Mufti of Egypt, Syauqi Ibrahim Allam stated: "Sexual violence against women is a major sin and the most heinous and evil act in the view of the Shari'ah. Sexual violence is only born from sick souls and low desires so that their desire is only to dissipate lust through animals, beyond logical reasoning and human reasoning".11

\section{d. Economic Violence (Domestic Abandonment)}

Abandonment in the household, in this case, is not providing for the wife. These forms of livelihood are not only for clothing, food, and shelter but also for ensuring or caring for and maintaining the wife's health in the form of medicines or other forms of livelihood. According to Ibn Qudamah, scholars agree on the obligation of the husband to provide for his wife when she is mature, except when the wife is disobedient. The fiqh experts have also agreed that the husband's wife's rights are maintenance and housing, as the word of Allah in Surah Al-Baqarah (2): 233, in naqli arguments both in the Koran, Hadith and Ijma 'explaining the obligation to provide a living is borne by on the husband's side, he is obliged to provide for his wife according to his ability and vice versa.|سكنو هن) which means "place them."

From the explanation above, it can be concluded that Article 9 of Law no. 23 of 2004 concerning the elimination of domestic violence regarding the husband's obligations in providing a living. There is no difference, and it is in line with Islamic law. Chapter III of the PKDRT Law, which explains the prohibition of acts of violence within the household scope in its manufacture, also considers the provisions in Islamic law. Suppose there is an act of violence in the household that violates the provisions of the

\footnotetext{
10Muhammad, H. (2013). Women-Friendly Religion Islam: Defense of Islamic Boarding School Kiai. Yogyakarta: LKIS Yogyakarta. p. 263.

${ }^{11}$ Swararahima. Islam Menolak Kekerasan Seksual. Retrieved from https://swararahima.com/2020/02/17/islam-menolak-kekerasan-seksual/, (accessed April 18, 2021).
} 
PKDRT Law. In that case, indirectly, the perpetrator of the act of violence also violates the provisions contained in the Al-Qur'an and Hadith, which are used as the basis for forming this law.

The PKDRT Law does not aim to compete with Islamic law but as a companion to existing Islamic law. Islamic law remains a guide to the best settlement if it is done correctly, while the law established by the State then helps solve it. Considering that violence is contrary to human rights, the State is obliged to respect, protect and fulfill the human rights of its citizens, especially the right to a sense of security and freedom from all forms of violence and discrimination.

\subsection{The Existence and Role of the Religious Court in Divorce Lawsuits on the grounds of Domestic Violence}

After the enactment of Law Number 7 of 1989 concerning the Religious Courts, there was hope to realize an independent Religious Court following statutory regulations. This hope has skyrocketed after the exposure of Law Number 3 of 2006 concerning Amendments to Law Number 7 of 1989 concerning the Religious Courts last with Law Number 50 of 2009 concerning the Second Amendment to Law Number 7 of 1989 concerning the Religious Courts. Make the Religious Courts stronger position in Indonesia.

The specific authority possessed by the religious courts as stated in Article 49 and Article 52 A of Law no. 3 of 2006 are:
"Religious courts have the duty and authority to examine, decide, and settle cases at the first level between people who are Muslim in the fields of a) marriage; b) inheritance; c) will; d) grants; e) waqf; f) zakat; g) infaq; h) sadaqah, and i) sharia economy."12

\footnotetext{
12The settlement of sharia economic disputes is a new authority within the religious courts. It covers extensive matters, including Sharia Banks, Sharia Microfinance Institutions, Sharia Insurance, Sharia Reinsurance, Sharia Mutual Funds, Sharia Bonds and Futures Securities, Sharia Securities, Sharia Financing, Sharia Pawnshops, Sharia Financial Institution Pension Funds, and Sharia Businesses. A full description of the authority of this religious Court can be seen in the Elucidation of Article 49 of Law no. 3 of 2006.
} 
"Religious courts provide istbat testimony of rukyat hilal in determining the beginning of the month in the Hijri year."13

So, the new authority possessed by the religious courts after the amendment of Law no. 7 of 1989 with Law no. 3 of 2006 is zakat, infaq, shadaqah, sharia economics, and itsbat as rukyat hilal. In the field of marriage, it is also mentioned in the article's explanation that there is an authority to determine the origin of a child and determine the adoption of a child based on Islamic law.

The authority to resolve disputes in the field of family law, in this case, marriage and inheritance, is still the authority of the religious Court. The material law used by the special religious courts regarding marital disputes is based on the provisions contained in Law no. 1 of 1974 concerning marriage and Presidential Instruction No. 1 of 1991 concerning the Compilation of Islamic Law. ${ }^{14}$ In addition to waqf in KHI (book 3), the material law of waqf is also contained in Law no. 41 of 2004 concerning waqf in which it has regulated money waqf or cash waqf, and the material law of zakat is Law no. 38 of 1999 concerning zakat which contains new material in the form of professional zakat.

From the description above, it can be understood that Article 49 of Law no. 3 of 2006 is the absolute competence of the religious courts. Thus, other courts are not authorized to resolve disputes as contained in Article 49 of Law no. 3 of 2006. Apart from absolute competence, there is also relative competence. ${ }^{15}$ From the religious

${ }^{13}$ So far, the religious courts have been asked by the Minister of Religion to give a determination (itsbat) to the testimony of people who have seen or witnessed the new moon every entering the month of Ramadan and the beginning of the month of Shawwal in the Hijri year in the context of the Minister of Religion issuing a national determination for the determination of 1 (one) Ramadan. And 1 (one) Shawwal. Religious courts can provide information or advice regarding differences in determining the direction of Qibla and determining prayer times. See, explanation article 52A, Law no. 3 of 2006.

${ }^{14}$ Regarding Islamic Law Compilation, which has a dress in the form of a Presidential Instruction, juridically, its enforcement force is weak. However, in practice, it is used as a guideline by religious courts in accepting, examining, and deciding disputes between Muslims in the field of marriage (book 1), inheritance (book 2), and waqf (book 3). The justice-seeking community did not mind it. Thus, the basis for the validity of KHI is based more on the condition that KHI (Indonesian fiqh) is a living law, namely a law that is obeyed by the community because it follows the conditions of the community and the legal awareness of the community. See., Aripin, J. (2008). Religious Courts in the Frame of Legal Reform in Indonesia, Cet. I. Jakarta: Kencana Prenada Media Group. p. 346.

${ }^{15} \mathrm{Absolute}$ competence (absolute competence) is the authority of the Court to judge based on material law. In contrast, relative competence is the power to judge based on the region or region. The 
Court. With the amendments to the law on religious courts, the religious courts have broader powers. In other words, the development of the religious courts is getting clearer. ${ }^{16}$ Furthermore, the existence of religious courts is getting stronger and stronger in the order of the national legal system.

Law No. 3 of 2006 contains 42 amendments to Law no. 7 of 1989, which was later amended by Law no. 50 of 2009 is a strong foundation for the solid position of the Religious Courts along with the authorities they have.

If observed in Law no. 50 of 2009, there are significant changes contained in Law no. 50 of 2009 concerning the Second Amendment to Law no. 7 of 1989 concerning the Religious Courts, which has laid the basis for policies in all matters concerning the religious courts, the highest supervision regarding both judicial and non-judicial technical matters, namely organizational, administrative, and financial affairs is under the authority of the Supreme Court. Meanwhile, to maintain and uphold judges' honor, dignity, and behavior, external supervision is carried out by the Judicial Commission. Second Amendment to Law no. 7 of 1989 concerning the Religious Courts is intended to strengthen the basic principles in the administration of judicial power, ${ }^{17}$

From the description above, it is clear that Religious Courts are courts that specifically deal with some instances between people who are Muslim or institutions based on sharia principles, so as far as the causal factors are concerned, domestic violence is only the cause or reason of the many reasons for divorce.

Observing the rise of domestic violence cases in the community sometimes creates a

relative authority of the religious Court is following its place and position. The religious Court is domiciled in the district capital, and its jurisdiction covers the city and district areas. The religious high Court is domiciled in the provincial capital, and its jurisdiction covers the province. See, Musthofa, Sy. (2005). Registrar of Religious Courts, Cet. I. Jakarta: Kencana. p. 9.

16Regarding the development of the Religious Courts in Indonesia, four essential aspects are related to these developments. First, concerning the position of the judiciary in the national legal and judicial system. Second, it relates to the composition of the judiciary, which includes the hierarchy and organizational structure of the courts, including the human resources component in them. Third, concerning the Court's authority, both absolute competency and relative competency. Fourth, procedural law is used as the basis for receiving, examining, deciding and resolving cases. See, Bisri, C. H. (1997). Islamic Courts in Indonesian Society. Bandung: Rosdakarya. p. 123.

${ }^{17}$ See the explanation of Law no. 50 of 2009. 
misperception among the community as if Islamic teachings tolerate domestic violence from husbands to wives. According to the views of anti-Islamic people, domestic violence is triggered by Islamic teachings that allow polygamy views and acts of beatings in the context of education. Domestic violence is caused by 2 (two) things. First, individual factors, namely the absence of piety in individuals, weak understanding of husband-and-wife relations in the household, and temperamental individual characteristics trigger someone to violate sharia law, including committing domestic violence. Second, systemic factors, namely the current violence, have become a social disease in society, both domestically and publicly. The violence that occurs is structurally caused by enacting a system that does not guarantee the community's welfare, ignores spiritual values, and denies the protection of human existence. This is due to the capitalist-secular system that separates religion and human life. ${ }^{18}$

A brief overview of all domestic violence cases in Indonesia, most complaints and resolutions of domestic violence cases are in the Religious Courts, namely 20,380 cases or $41 \%$. This number also shows that divorce cases in the Religious Courts are mostly related to domestic violence cases.

Referring to Article 1 of Law Number 23 of 2004 concerning the Elimination of Domestic Violence (UU PKDRT) states that "Domestic violence is any act against a person, especially a woman, which results in physical, sexual, psychological misery or suffering and/or neglect of the home. Including threats to commit acts, coercion, or deprivation of liberty unlawfully within the scope of the household".19

Mustofa Hasan said that "domestic violence is a form of crime that occurs in the household that is committed by a husband to his wife or vice versa by a wife to her husband..$^{20}$

\footnotetext{
18Suadi, A., et al. (2016). Legal Politics: Perspectives on Islamic Civil and Criminal Law and Sharia Economics, Cet. II. Jakarta: Kencana. p. 131.

${ }^{19}$ See article 1, Law Number 23 of 2004 concerning the Elimination of Domestic Violence.

${ }^{20}$ See Hasan, M. (2011). Introduction to Family Law, Cet. II. Bandung: Faithful Library. p. 363. As quoted by Ahmad, B. and Yanti, Y. (2015). The Existence and Implementation of Islamic Law in Indonesia, Cet. I. Yogjakarta: Student Library. p. 171.
} 
Article 6 of the PKDRT Law states that "Physical violence is an act that causes pain, falls ill, or is seriously injured. ${ }^{21}$

In her book Women and the Resolution of Domestic Violence, Rika Saraswati says that "any act that results in pain, injury, injury, or disability in a person's body, abortion, unconsciousness and/or death. ${ }^{22}$

Physical violence can be divided into 2 (two), namely severe physical violence and mild physical violence. Severe physical violence in the form of severe abuse such as kicking, hitting, attempting murder or murder, and all other actions that can result in being unable to carry out daily tasks, losing one of the five senses, getting disabled, and others. While mild physical violence in the form of slapping, pushing, and other actions that result in minor injuries, bruises, etc. ${ }^{23}$

Law Number 1 of 1974 concerning marriage is one of the sources of material law applied in the Religious Courts which is very concerned about gender equality, and this can be seen from several principles in the law, namely:

1. The principle of complicating divorce;

2. The principle of monogamy;

3. The principle of agreement between the two prospective brides;

4. The principle of balance between husband and wife in fostering a household;

5. File a case at the wife's residence/wife's place of residence.

As explained in Article 39 paragraph (2) of Law no. 1 of 1974 jo, in response to the above. Article 19 of PP No. 9 of 1975 concerning the Implementation of Law no. 1 of 1974 jo. Article 116 of the Compilation of Islamic Law, it is emphasized that the reasons on which a person can file for divorce in the Religious Courts are:

1. one of the parties commits adultery or becomes a drunkard, compactor, gambler, and so on, which is difficult to cure;

\footnotetext{
21See, Article 6 of Law Number 23 of 2004 concerning PKDRT.

${ }^{22} \mathrm{Ahmad}, \mathrm{B}$. and Yanti, Y. (2015). The Existence and Implementation of Islamic Law in Indonesia, Cet. I. Yogjakarta: Student Library. p. 172. For more details see, Saraswati, R. (2009). Women and the Resolution of Domestic Violence. Bandung: Citra Aditya Bakti. p. 22.

${ }^{23}$ Ibid.
} 
2. one of the parties leaves the other party for two consecutive years without the permission of the other party and a valid reason or for other reasons beyond his control;

3. one of the parties gets a prison sentence of 5 years or a heavier sentence after the marriage takes place:

4. one of the parties commits atrocities, severe persecution that endangers the other party:

5. one of the parties gets a disability or disease with the result that they are unable to carry out their obligations as husband/wife;

6. There are constant disputes and quarrels between husband and wife, and there is no hope of living in harmony again in the household.

From the reasons mentioned above, it can be understood that in the case of domestic violence, it is included in category number 4 (four). In the process of resolving divorce cases at the Religious Court on the grounds of domestic violence, in general, when registering the case or in the trial examination, the wife does not want to reveal the reasons for domestic violence as an excuse. Divorce in his claim, for various reasons such as the wife, does not want to prolong the problem with her husband and has to disclose the incidents of domestic violence that happened to her until her family finds out, or there is a reason because the wife does not have strong witness evidence to prove it in the case of domestic violence to be proven in the case-the judge. Some do not want to for reasons of maintaining the psychological condition of the children.

Furthermore, let's look at domestic violence as regulated by Law Number 23 of 2004 concerning the Elimination of Domestic Violence (PKDRT law). It is relevant to Law Number 1 of 1974 as amended by Law Number 16 of 2019 concerning marriage in article 39 paragraph 1 and paragraph 2 states:

(1) Divorce can only be carried out before a Court Session after the Court concerned has tried and failed to reconcile the two parties.

(2) In order to divorce, there must be sufficient reason that the husband and wife will not be able to live in harmony as husband and wife. 
Likewise, the provisions of Article 19 of Government Regulation Number 9 of 1975 concerning the implementation of the Marriage Law state the reasons that can be used as the basis for divorce, which indicate factors of domestic violence which can be explained as follows:

a. One of the parties commits adultery or becomes a drunkard, compactor, gambler, etc. which is difficult to cure;

- This reason can be categorized as psychological violence because bad habits in letter (a) will affect the decrease in family property and cause reduced income to meet daily life.

b. One of the parties leaves the other party for 2 (two) consecutive years without the permission of the other party and a valid reason or for other reasons beyond his control;

c. One of the parties gets a prison sentence of 5 (five) years or a heavier sentence after the marriage takes place.

- The reasons for letters (b) and (c) can also be categorized as a form of psychological violence because the condition of the household can lead to uncertainty about marital status, uncertainty about the responsibilities of one party as a parent, and uncertainty in living if the husband does not at all provide a living so that such conditions can also be categorized as economic violence or neglect of the household.

d. One of the parties commits atrocities or severe persecution that endangers the other party;

- This reason can also be categorized as a form of physical violence. The use of the word cruelty can be interpreted as physical violence and acts such as poisoning. Meanwhile, severe abuse and endangering the lives of others are physical violence.

e. One of the parties gets a disability or illness as a result of not being able to carry out their obligations as husband/wife;

- This reason can also be categorized as a form of psychic violence because it 
tends to ignore the feelings of someone who, after being disabled, are then abandoned. This is like the phrase "it is good to be thrown away." When healthy, there is no problem, but after experiencing a disability or disease, then abandoned. Legislators only look at the physical side of a person and ignore someone that people are not inanimate objects that are quickly thrown away.

f. There are constant disputes and quarrels between husband and wife, and there is no hope of living in harmony again in the household.

- This reason can also be categorized as a form of psychological violence because the condition of a household that fights or disagrees continuously and cannot be significantly reconciled disturbs the thoughts and survival of the family members who live in it.

From the provisions of Article 39 paragraph 1 and paragraph 2, as well as the reasons for divorce in Article 19 of Government Regulation Number 9 of 1975 above, it has been shown that there is a role in settlement of divorce cases in the Religious Court as a result of factors of domestic violence as referred to in the PKDRT Law.

In response to the description above, a household which, if built on the foundation of faith and piety and morals from husband and wife, and each realizes his role and carries out his rights and obligations according to Islamic law, will undoubtedly be able to pioneer and build a good household. Sakinah mawaddah wa rahmah, there is no need for violence. Domestic violence can be avoided because the household is built on the foundation of Islamic law, based on love and affection, mutual respect, mutual respect, mutual help, loyalty, honesty, and adequate physical and spiritual support.

\section{Conclusion}

In a review of Law Number 23 of 2004, whatever its nature is hitting the wife is one type of domestic violence that is prohibited by the PKDRT law, but in essence, the law on domestic violence does not conflict with Islamic teachings because the law was made to protect the benefit of the community, namely protecting every member of the family or household from acts of violence, as well as Islam with its principle as 
rahmatan lil 'alamin, one of which is by stipulating the reasons for divorce in Law Number 1 of 1974 as amended by Law Number 16 of 2019 concerning marriage and Government Regulation Number 9 of 1975 concerning the implementation of the Marriage Law which can be categorized as acts of domestic violence. While the role of the Religious Court has played an active role in applying the law in handling divorce lawsuits on the grounds of domestic violence by applying the provisions of article 39, paragraph 1 and paragraph 2 and the reasons for divorce in article 19 of Government Regulation No. 9 of 1975.

\section{References}

Wahid, A. and Irfan, M. (2001). Protection of Victims of Sexual Violence. Bandung: Refika Aditama.

Abdurrahman. (1992). Compilation of Islamic Law, Cet. I. Jakarta: Akademika Pressindo.

Suadi, A., et al. (2016). Legal Politics: Perspectives on Islamic Civil and Criminal Law and Sharia Economics, Cet. II. Jakarta: Kencana.

Ahmad, B. and Yanti, Y. (2015). The Existence and Implementation of Islamic Law in Indonesia, Cet. I. Yogjakarta: Student Library.

Bisri, C. H. (1997). Islamic Courts in Indonesian Society. Bandung: Rosdakarya.

Wardah, F. Korban KDRT Lebih Memilih Perceraian daripada Pidana. Retrieved from https://www.voaindonesia.com/a/korban-kdrt-masih-select-perbagiandaripada-pidana-/5141998.html, (accessed April 18, 2021).

Aripin, J. (2008). Religious Courts in the Frame of Legal Reform in Indonesia, Cet. I. Jakarta: Kencana Prenada Media Group.

Muhammad, H. (2013). Women-Friendly Religion Islam: Defense of Islamic Boarding School Kiai. Yogyakarta: LKIS Yogyakarta.

Komnas Perempuan. (2020). 2019 Annual Record of Violence Against Women. Jakarta: Komnas Perempuan

Soeroso, M. H. (2010). Domestic Violence in Juridical-Victimological Perspective. Jakarta: Sinar Grafika

Ali, M. D. (2002). Islamic Law and Religious Courts, (Collection of Writings), Cet. II. Jakarta: Raja Grafindo Persada.

Dewata, M. F. N. and Ahmad, Y. (2013). Dualism of Normative and Empirical Legal Research. Yogyakarta: Pustaka Pelajar. 
Musthofa, Sy. (2005). Registrar of Religious Courts, Cet. I. Jakarta: Kencana.

Hasan, M. (2011). Introduction to Family Law, Cet. II. Bandung: Faithful Library.

Marzuki, P. M. (2014). Legal Research. Jakarta: Prenamedia Group.

Saraswati, R. (2009). Women and the Resolution of Domestic Violence. Bandung: Citra Aditya Bakti.

Latif, S. M. N. (2005). Marriage Counseling, Cet. II. Bandung: Hidayah Library.

Soekanto, S. and Mamudji, S. (2013). Normative Legal Research. Jakarta: Rajawali Pers

Mertokusumo, S. (2007). The Discovery of An Introduction to Law. Yogyakarta: Liberty

Swararahima. Islam Menolak Kekerasan Seksual. Retrieved from https://swararahima.com/2020/02/17/islam-menolak-kekerasan-seksual/, (accessed April 18, 2021).

\section{Laws}

Law Number 3 of 2006 concerning Amendments to Law Number 7 of 1989

Law Number 23 of 2004 concerning Elimination of Domestic Violence. 